\title{
Complementary and alternative medicine use for weight management among females in Jordan: a community-based survey
}

Mayadah Bashir Shehadeh, ${ }^{1}$ Ghadeer Suaifan, ${ }^{1}$ Alaa Abu-Odeh ${ }^{2}$ and Rula Darwish ${ }^{3}$

${ }^{1}$ Department of Pharmaceutical Sciences. ${ }^{2}$ School of Pharmacy, University of Jordan, Amman, Jordan (Correspondence to: Mayadah Shehadeh: m.shehadeh@ju.edu.jo). ${ }^{3}$ Department of Pharmaceutics and Pharmaceutical Biotechnology, University of Jordan, Amman, Jordan.

\begin{abstract}
Background: The relationship between obesity and various chronic diseases is well documented. In Jordan, the prevalence of overweight (30.0\%) and obesity (38.8\%) among females is on the rise, encouraging many adults to rely on alternative health care methods to manage their weight.
\end{abstract}

Aims: We explored the status of complementary and alternative medicine use for weight management among adult females in Jordan and the possible relationship between complementary and alternative medicine use and body mass index.

Methods: An interviewer-administered, structured questionnaire was used to collect data on the use and safety of complementary and alternative medicine for weight management from 858 women in 2015. Responses were coded and analysed using SPSS, version 20.

Results: Around $40 \%$ of the respondents reported using some form of complementary and alternative medicine for weight management. Commercial dietary supplements $(31.2 \%)$, herbal remedies $(26.7 \%)$ and folk remedies $(18.0 \%)$ were commonly used. Green tea and fibre tablets were the most widely used herbal supplements. Logistic regression analysis indicated that overweight participants are more frequent complementary and alternative medicine users compared to obese. Relatives and friends were the main sources of information about complementary and alternative medicine. Only $31.9 \%$ of women believed that complementary and alternative medicine modalities were safe; around half believed they were not safe during pregnancy (52.5\%) and lactation (48.0\%). Only $49.7 \%$ were aware of side-effects and $41.5 \%$ of drug interactions.

Conclusion: This study revealed that complementary and alternative medicine is often used for weight management. Awareness of the safe use of complementary and alternative medicine with other medications and during pregnancy and lactation should be addressed.

Keywords: alternative medicine, dietary supplements, weight management, women, Jordan

Citation: Shehadeh M; Suaifan G; Abu-Odeh A; Darwish R. Complementary and alternative medicine use for weight management among females in Jordan; a community-based survey. East Mediterr Health J. 2020;26(4):443-452.https://doi.org/10.26719/emhj.19.098

Received: 10/02/18; accepted: 03/09/18

Copyright (c) World Health Organization (WHO) 2020. Open Access. Some rights reserved. This work is available under the CC BY-NC-SA 3.0 IGO license (https://creativecommons.org/licenses/by-nc-sa/3.o/igo).

\section{Introduction}

Despite recent advances in care and management, the obesity epidemic has reached an alarming level worldwide in both developing and developed countries. Globally, one billion adults have been identified as being overweight and 300 million as obese (1). Jordan is ranked 25th among countries suffering from obesity, with a prevalence of $49.7 \%$ (2). Overweight and obesity among women in Jordan has reached alarming levels $330.0 \%$ and $38.8 \%$ respectively). Changes in physical activity, lifestyle, socioeconomic status and dietary habits are factors which have been found to be associated with precipitating obesity (3-5).

Obesity causes substantial morbidity, mortality and chronic complications. Recent research has highlighted it as a risk factor for coronary heart disease. In addition, obesity is associated with hypertension, diabetes, dyslipidaemia, cancer, osteoarthritis of weight-bearing joints and deteriorating quality of life $(3,6)$.

Enormous advances have been accomplished in modern medicine, however, complementary and alternative medicine (CAM) still interests people greatly. In many developing countries, traditional medicine is the primary health care system, with about $70-80 \%$ of the population relying on it (7). One-third of adults in the United States of America have used some form of CAM according to the 2002 National Health Interview Survey and several population-based studies $(4,5,7,8)$. Herbs (35.5\%) and hijama (cupping) (20.4\%) are the most widely used forms of CAM in Jordan for cancer patients and the chronically ill (9). Other commonly used CAM therapies include herbal products, deep breathing exercises, meditation, chiropractic, yoga, massage and diet-based therapies $(4,10,11)$. Complementary and alternative medicine encompasses various ancient and new approaches which are not taught widely in medical schools and are not generally used in hospitals for the purpose of preventing or treating disease. By definition, complementary practices are used together with conventional medicine, while alternative methods are used instead of conventional therapy $(4,10,11)$.

"Back to nature" is one of several aspects that have encouraged the expansion of CAM use: it adds to the 
perception among consumers that these practices are natural and therefore safe and cannot cause harm. The high cost of conventional therapies and the trend towards self-medication also have contributed to the expansion in use. In particular, individuals who are obese are seeking alternative practices for weight management due to the poor compliance with conventional weight-management programmes, indicating that there is a need for safe, effective and acceptable therapeutic options $(5,10,12,13)$.

Our objectives were to determine the status and perception of safety of CAM use as a weight control or weight reduction intervention among a sample of normal, overweight and obese females in Jordan and to examine any possible relationship between body mass index (BMI) and such use.

\section{Methods}

\section{Study population and study tool}

A face-to-face (participants completed the questionnaire in front of the distributer), anonymous, structured questionnaire was administered to a sample of adult women (any woman who appeared to be 18 years old or older; target sample was set at 1000) after obtaining verbal informed consent to participate in the study (the consent statement was clearly printed at the top of the questionnaire and was recited to each prospective participant. The study was carried out in various community settings to ensure sample representativeness ( 5 health care centres, 5 shopping malls, 10 supermarkets, the University of Jordan main cafeteria, 3 fitness centres and 10 female beauty centres).

The questionnaire was developed by the researchers and structured to cover commonly used CAM modalities in Jordan. It was approved by an expert panel comprising 2 nutritionists, 3 pharmacists and a statistician. To ensure validity and to facilitate data collection, the questionnaire was constructed in English first, then translated into Arabic and back to English. Back translation was undertaken by a bilingual speaker to ensure translation validity. The sample size of 600 participants was computed using the sample size calculator (surveysystem.com) with confidence interval of 4 , confidence level of $95 \%$ based on the females population aged 18+ years, at the end of 2014 this was 2667640 (data from the Department of Statistics, Jordan DOS 2014).

A preliminary trial was conducted on a sample of around 25 females (4.2\% of the target sample) to address any ambiguity in the questions. Data collected during this pilot study was excluded from the final data analysis. All feedback received was incorporated into the final amended Arabic version of the questionnaire, which was then distributed to the research assistants and then to the respondents. The questionnaire comprised 25 questions divided into 4 sections. The first section collected demographic data, the second was about health status (if the participant had any chronic disease), the third section addressed different types of CAM and the last section focused on CAM safety.
As in many research studies, participant recruitment was a major challenged. This is because recruitment includes the identification of participants eligible for the study goals and design, the proper explanation of the study to potential participants, informed verbal consent and ethical standards being maintained. Accordingly, fifth-year pharmacy students were trained to ensure efficient communication with potential participants. The average interview time was 20-30 minutes.

Data were collected between February and June 2015. Respondents were categorized according to the internationally defined BMI categories: normal (18.5 to < $\left.25 \mathrm{~kg} / \mathrm{m}^{2}\right)$; overweight $\left(25.0\right.$ to $\left.<30 \mathrm{~kg} / \mathrm{m}^{2}\right)$; obese $(\geq 30 \mathrm{~kg} /$ $\left.\mathrm{m}^{2}\right)$.

\section{Data analysis}

Data were coded, entered and analysed using SPSS, version 20. The analysis involved descriptive quantitative statistics, e.g. frequency and percentage. Binary stepwise logistic regression analysis was used to determine the associations between CAM modalities used and respondents' BMI status. Using the forward Wald method, odds ratios (ORs) and their 95\% confidence intervals (CIs) were computed. $P$-value $\leq 0.05$ was considered to be statistically significant. The chi-squared test was performed to explore the differences in health habits between CAM users and nonusers.

\section{Compliance with ethical standards}

Informed consent was obtained from all individuals included in the study. No financial incentive was offered. This study was approved by the Scientific Research Committee at the Faculty of Pharmacy and the University of Jordan and the institutional review board of Jordan University Hospital.

\section{Results}

We recruited 858 women to participate in the study. Participants with a BMI below $18.5 \mathrm{~kg} / \mathrm{m}^{2}(4.7 \%)$ were excluded from the data analysis. Data collected from 818 females were subjected to analysis (95.3\%). The majority of respondents were young (423 aged 18-25 years), university graduates (507), single (449) and had a medium monthly income (500-1500 Jordanian dinars/month) (Table 1). Nearly half (42.2\%) the respondents were classified as overweight (BMI $\geq 25-29.9 \mathrm{~kg} / \mathrm{m}^{2}$ ) or obese (BMI $\geq 30 \mathrm{~kg} / \mathrm{m}^{2}$ ). Overweight was very common (9.8\%) among the youngest age group (18-25 years) while obesity (7.1\%) was common in the oldest group ( $\geq 46$ years); $8 \%$ of obese respondents considered their weight to be normal.

Use of CAM was reported by participants in all BMI categories. Several strategies had been adopted to maintain or lose weight. Overall, $54.3 \%$ of our participants tried to reduce or control their weight in the previous year. Only, 38.9\% reported the use of at least one form of CAM therapy for weight reduction or weight control (Table 2). However, more of those in the obese group tended to rely on CAM modalities to reduce their weight (63.3\%) compared to overweight $(46.1 \%)$ and normal 


\begin{tabular}{|c|c|c|c|c|c|c|c|}
\hline \multirow[t]{2}{*}{ Characteristic } & \multirow[t]{2}{*}{ Overall } & \multicolumn{2}{|c|}{ Normal weight } & \multicolumn{2}{|c|}{ Overweight } & \multicolumn{2}{|c|}{ Obese } \\
\hline & & No. & $\%$ & No. & $\%$ & No. & $\%$ \\
\hline Sample size & 818 & 471 & 57.6 & 219 & 26.8 & 128 & 15.6 \\
\hline \multicolumn{8}{|l|}{ Age (years) } \\
\hline $18-25$ & 423 & 330 & 78.0 & 80 & 18.9 & 13 & 3.1 \\
\hline $26-30$ & 78 & 46 & 59.0 & 22 & 28.2 & 10 & 12.8 \\
\hline $31-35$ & 69 & 34 & 49.3 & 22 & 31.9 & 13 & 18.8 \\
\hline $36-40$ & 56 & 18 & 32.1 & 27 & 48.2 & 11 & 19.6 \\
\hline $41-45$ & 74 & 22 & 29.7 & 30 & 40.5 & 22 & 29.7 \\
\hline$\geq 46$ & 114 & 19 & 16.7 & 37() & 32.5 & 58 & 50.9 \\
\hline No answer a & 4 & 2 & & 1 & & 1 & \\
\hline \multicolumn{8}{|l|}{ Education level } \\
\hline Primary school & 28 & 7 & 25.0 & 4 & 14.3 & 17 & 60.7 \\
\hline High school & 98 & 30 & 30.6 & 35 & 35.7 & 33 & 33.7 \\
\hline Community college & 113 & 45 & 39.8 & 33 & 29.2 & 35 & 31.0 \\
\hline University graduate & 507 & 345 & 68.1 & 130 & 25.6 & 32 & 6.3 \\
\hline Postgraduate & 59 & 37 & 62.7 & 13 & 22.0 & 9 & $15 \cdot 3$ \\
\hline No answer ${ }^{b}$ & 13 & 7 & & 3 & & 2 & \\
\hline \multicolumn{8}{|l|}{ Income (JOD/month) ${ }^{b}$} \\
\hline Less than 500 (low) & 156 & 73 & 46.8 & 44 & 28.2 & 39 & 25.0 \\
\hline 500-1500 (medium) & 420 & 262 & 62.4 & 105 & 25.0 & 53 & 12.6 \\
\hline More than 1500 (high) & 217 & 122 & 56.2 & 62 & 28.6 & 33 & 15.2 \\
\hline No answer a & 25 & 14 & & 8 & & 3 & \\
\hline \multicolumn{8}{|l|}{ Marital status } \\
\hline Single & 449 & 341 & 75.9 & 91 & 20.3 & 17 & 3.7 \\
\hline Married & 328 & 121 & 36.9 & 116 & 12.2 & 91 & 27.4 \\
\hline Divorced & 17 & 8 & 47.0 & 6 & $35 \cdot 3$ & 3 & 17.6 \\
\hline Widowed & 22 & 1 & 4.5 & 5 & 22.7 & 16 & 72.7 \\
\hline No answer ${ }^{a}$ & 2 & 0 & & 1 & & 1 & \\
\hline \multicolumn{8}{|l|}{ Occupation } \\
\hline School student & 18 & 14 & 77.8 & 1 & 5.6 & 3 & 16.7 \\
\hline University student & 336 & 262 & 78.0 & 67 & 19.9 & 7 & 2.1 \\
\hline Business owner & 22 & 8 & 36.4 & 8 & 36.4 & 6 & 27.3 \\
\hline Private sector employee & 84 & 57 & 67.9 & 18 & 21.4 & 9 & 10.7 \\
\hline Public sector employee & 117 & 54 & 46.2 & 45 & 38.5 & 18 & 15.4 \\
\hline Housewife & 188 & 53 & 29.2 & 66 & 35.1 & 69 & 36.7 \\
\hline Retired & 13 & 2 & 15.4 & 2 & 15.4 & 9 & 69.2 \\
\hline Unemployed & 23 & 11 & 47.8 & 8 & 34.8 & 4 & 17.4 \\
\hline Other & 4 & 2 & 50.0 & 1 & 25.0 & 1 & 25.0 \\
\hline No answer ${ }^{\text {a }}$ & 13 & 8 & & 3 & & 2 & \\
\hline
\end{tabular}

${ }^{a}$ Not included in statistical analysis.

${ }^{b} U S \$ 1=$ JOD 0.71 (Jordanian dinars).

Normal weight $\left(18.5\right.$ to $\left.<25 \mathrm{~kg} / \mathrm{m}^{2}\right)$; overweight $\left(25.0\right.$ to $\left.<30 \mathrm{~kg} / \mathrm{m}^{2}\right)$; obese $\left(<30 \mathrm{~kg} / \mathrm{m}^{2}\right)$.

weight (28.9\%) (Table 3).

Commercial dietary products (29.5\%), herbal remedies (24.7\%) and herbal dietary supplements (16.9\%) were the most commonly used CAM modalities (Figure 1). Nonprescription medications (77; 9.4\%), massage (28; 3.4\%), aromatherapy $(25 ; 3.1 \%)$, yoga $(25 ; 3.1 \%)$ and acupuncture
(12; 1.5\%) were less popular among participants $(P<0.05)$ (Figure 1).

The main source of information about herbal dietary products (19.4\%) and herbal remedies (25.8\%) was relatives and friends, followed by the herbalist (attar) (10.1\% and $11.0 \%$ respectively), pharmacists $(9.0 \%$ and $7.0 \%$, 


\begin{tabular}{|c|c|c|c|c|c|c|c|}
\hline \multirow[t]{2}{*}{ Health habit } & \multirow{2}{*}{$\begin{array}{l}\text { Overall } \\
\text { sample }\end{array}$} & \multicolumn{2}{|c|}{ Normal weight } & \multicolumn{2}{|c|}{ Overweight } & \multicolumn{2}{|c|}{ Obese } \\
\hline & & No. & $\%$ & No. & $\%$ & No. & $\%$ \\
\hline Sample size & 818 & 471 & 57.6 & 219 & 26.8 & 128 & 15.6 \\
\hline \multicolumn{8}{|l|}{ Physical activity } \\
\hline Yes & 381 & 183 & 38.9 & 120 & 54.8 & 78 & 60.9 \\
\hline No & 437 & 288 & 61.2 & 99 & 45.2 & 50 & 39.1 \\
\hline \multicolumn{8}{|c|}{ Any chronic disorder } \\
\hline Yes & 116 & 21 & 4.5 & 39 & 17.8 & 56 & 43.8 \\
\hline No & 701 & 450 & 95.5 & 180 & 82.2 & 71 & $55 \cdot 5$ \\
\hline No answera & 1 & 0 & & 0 & & 1 & \\
\hline \multicolumn{8}{|c|}{ Use complementary and alternative medicine for chronic disorder } \\
\hline Yes & 117 & 31 & 6.6 & 53 & 24.2 & 33 & 25.8 \\
\hline No & 680 & 426 & 90.2 & 161 & 73.5 & 93 & 72.7 \\
\hline No answer ${ }^{a}$ & 21 & 15 & & 5 & & 2 & \\
\hline \multicolumn{8}{|c|}{ Weight reduction or control in previous 12 months } \\
\hline Yes & 444 & 202 & 42.9 & 148 & 67.6 & 94 & 73.4 \\
\hline No & 369 & 268 & 56.9 & 67 & 30.6 & 34 & 26.6 \\
\hline No answer ${ }^{a}$ & 5 & 1 & & 4 & & 0 & \\
\hline \multicolumn{8}{|c|}{ Using CAM for weight reduction or control } \\
\hline Yes & 318 & 136 & 28.9 & 101 & 46.1 & 81 & 63.9 \\
\hline No & 500 & 335 & 71.1 & 118 & 53.9 & 47 & 36.7 \\
\hline
\end{tabular}

${ }^{a}$ Not included in statistical analysis.

respectively), nutritionists ( $16.9 \%$ and $17.8 \%$, respectively), health food stores $(10.5 \%$ and $11.3 \%$, respectively), physicians (13.4\% and $12.5 \%$ respectively) and others (14.6\% and $9.9 \%$, respectively).

Prescription medications (77;10.0\%), massage $(28 ; 3.6 \%)$, aromatherapy $(25 ; 3.3 \%)$, yoga $(25 ; 3.3 \%)$ and acupuncture (12; $1.6 \%)$ were less popular among participants (Figure 1) $(P<0.05)$.Commercial dietary supplements and herbal remedies were the most widely used CAM modalities. Green tea was the most commonly used herbal drink (Figure 2), while ginger was the most widely used home remedy (Figure 3). Fat metabolizers and fibre tablets were the most widely used folk remedies among normal weight females (Figures 2,3).

Lifestyle habits and health status of the participants are summarized in Table 2. Lack of physical activity was common (437; 53.4\%). Utilization of CAM was greater among the chronically ill overweight and obese (72.8\%). Chronically ill overweight and obese women were more likely to use CAM (6.5\% and $4.0 \%$ respectively; $P<0.05)$ to treat their conditions.

Logistic regression analysis showed that BMI has no effect on the tendency of participants to rely on a specific type of CAM to maintain or reduce weight. (Table 4). Bivariate analysis did not reveal any statistically significant association between the CAM type used and BMI $(P \geq 0.05)$. However, it was observed that overweight respondents $\left(B M I \geq 25-29.9 \mathrm{~kg} / \mathrm{m}^{2}\right)$ were more likely to use aromatherapy (OR 12.17; 95\% CI: $0.96-153.58$ ) in attempting to reduce weight (Table 4).
Table 4 summarizes the sociodemographic characteristics of CAM users compared to nonusers. In general, there were significant differences in the characteristics of CAM users compared with nonusers in terms of education and occupation. Four in 10 working females were overweight and around 15\% were obese. Obesity (30\%) and overweight (37\%) were more common among housewives (Table 1).

A third of the respondents (31.9\%) believed that CAM is generally safe (Table 5). However, half of the participants (49.7\%) agreed that CAM modalities might induce sideeffects, $35.5 \%$ thought it might cause allergy and $41.5 \%$ that drug interactions were possible. Almost half of the participants opposed CAM use by pregnant $(52.5 \%)$ or lactating mothers (48\%).

\section{Discussion}

In Jordan, obesity among women of reproductive age is on the rise as indicated in the Jordan Population and Family Health Survey: the prevalence of overweight was 27\% while obesity was $20 \%$ (15). In our sample, $42.4 \%$ of the respondents did not have ideal body weight and were either overweight $(26.8 \%)$ or obese $(15.6 \%)$. Our findings are in line with a 2014 survey which reported $30.0 \%$ of females in Jordan are overweight and 38.8\% are obese, reflecting the lack of appropriate knowledge of what constituted a healthy weight (2). Over the past decade, Jordan has witnessed rapid changes towards a sedentary lifestyle, and a high-fat diet is common (14).

The high prevalence of CAM use among our 


\begin{tabular}{|c|c|c|c|c|c|}
\hline \multirow[t]{2}{*}{ Characteristic } & \multicolumn{2}{|c|}{ CAM user } & \multicolumn{2}{|c|}{ CAM non-user } & \multirow[t]{2}{*}{ P-value } \\
\hline & No. & $\%$ & No. & $\%$ & \\
\hline \multicolumn{6}{|l|}{ BMI } \\
\hline Normal & 136 & $28.9^{\mathrm{a}}$ & 335 & $71.1^{\mathrm{a}}$ & \multirow[t]{3}{*}{$<0.001$} \\
\hline Overweight & 101 & $46.1^{\mathrm{a}}$ & 118 & $53.9^{a}$ & \\
\hline Obese & 81 & $63 \cdot 3^{\mathrm{a}}$ & 47 & $36.7^{\mathrm{a}}$ & \\
\hline Age (years) & 318 & & & & \\
\hline $18-25$ & 145 & 45.6 & 278 & 55.0 & \multirow[t]{6}{*}{$<0.05$} \\
\hline $26-30$ & 31 & 9.7 & 47 & 9.4 & \\
\hline $31-35$ & 24 & 7.5 & 45 & 9.0 & \\
\hline $36-40$ & 23 & 7.2 & 33 & 6.6 & \\
\hline $41-45$ & 36 & 11.3 & 38 & 7.6 & \\
\hline$\geq 46$ & 56 & 17.6 & 58 & 11.6 & \\
\hline \multicolumn{6}{|l|}{ Income (JOD/month) ${ }^{b}$} \\
\hline Less than 500 (low) & 57 & 7.0 & 99 & 12.1 & \multirow[t]{4}{*}{0.145} \\
\hline 500-1500 (medium) & 154 & 18.8 & 266 & 32.5 & \\
\hline More than 1500 (high) & 100 & 12.2 & 117 & 14.3 & \\
\hline No answer ${ }^{c}$ & 7 & & 18 & & \\
\hline \multicolumn{6}{|l|}{ Education } \\
\hline Primary school & 6 & 0.7 & 22 & 2.7 & \multirow[t]{6}{*}{0.024} \\
\hline High school & 42 & 5.1 & 56 & 6.8 & \\
\hline Community college & 55 & 6.7 & 58 & 7.1 & \\
\hline University graduate & 184 & 22.5 & 323 & 39.5 & \\
\hline Postgraduate & 27 & $3 \cdot 3$ & 32 & 3.9 & \\
\hline No answer ${ }^{c}$ & 4 & & 9 & & \\
\hline \multicolumn{6}{|l|}{ Occupation } \\
\hline School student & 3 & 0.4 & 15 & 1.8 & \multirow[t]{10}{*}{$<0.001$} \\
\hline University student & 107 & 13.1 & 229 & 28.0 & \\
\hline Business owner & 11 & 1.3 & 11 & 1.3 & \\
\hline Private sector employee & 30 & 3.7 & 54 & 6.6 & \\
\hline Public sector employee & 47 & 5.8 & 70 & 8.6 & \\
\hline Housewife & 96 & 11.8 & 92 & 11.3 & \\
\hline Retired & 8 & 1.0 & 5 & 0.6 & \\
\hline Unemployed & 10 & 1.2 & 13 & 1.6 & \\
\hline Other & 0 & 0.0 & 4 & 0.5 & \\
\hline No answer ${ }^{c}$ & 5 & & 7 & & \\
\hline
\end{tabular}

${ }^{a}$ Calculated from the corresponding group.

${ }^{b} U S \$ 1=$ JOD 0.71 (Jordanian dinars).

'Not included in statistical analysis.

$P$-value was based on chi-squared test, $P<0.05 ; P<0.001$.

Body mass index (BMI): normal $\left(18.5\right.$ to $\left.<25 \mathrm{~kg} / \mathrm{m}^{2}\right)$; overweight $\left(25.0\right.$ to $\left.<30 \mathrm{~kg} / \mathrm{m}^{2}\right)$; obese $\left(\geq 30 \mathrm{~kg} / \mathrm{m}^{2}\right)$.

participants, mainly among those who were overweight, may be attributed to several factors. According to previous studies, influencing factors might include; the accessibility and availability of CAM products; the discrepancy between the expectations of the participants and the results achieved with conventional calorie reduction plans leading to a negative perception for their weight loss pattern; believing that CAM modalities are safe; difficulty in maintaining a healthy lifestyle; and the low rate of fulfilment of the objectives of a weight management nutrition plan $(5,16,17)$.

Our study indicated that both young females (18-25 years old) $45.6 \%$ and older individuals ( $\geq 46$ years old) $17.6 \%$ were more likely to use CAM. Green tea is the second most popular beverage worldwide after water (18) and we found it to be the most commonly used herbal drink by normal, overweight and obese participants 
Figure 1 Prevalence of complementary and alternative medicine modality utilization according to weight category in a sample of Jordanian women $(n=818), 2015$

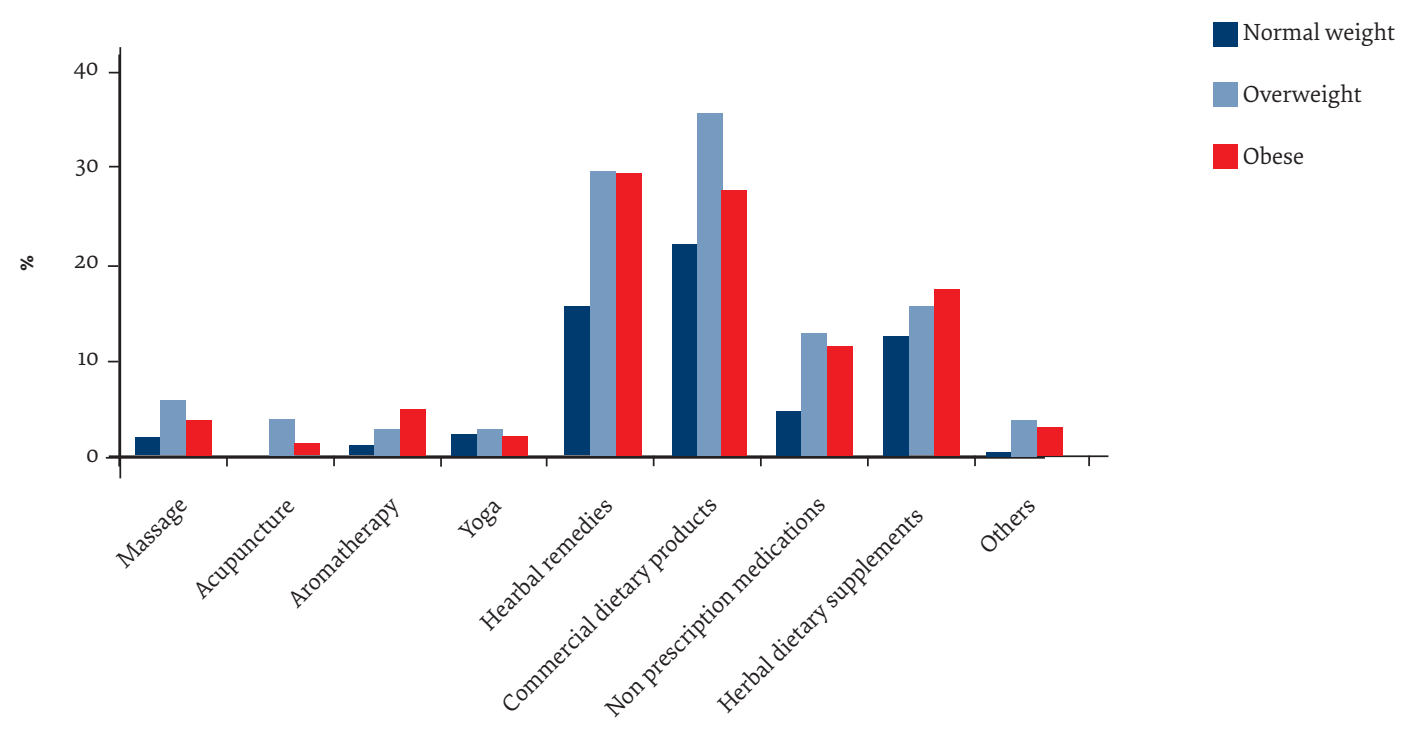

complementary and alternative medicine modality

in our study. This may be explained by the influence of media hype on the benefits of green tea, according to Sae-Tan et al. (19). Another potential explanation for the popularity of green tea and similar herbal and home remedies is that dietary supplements are not perceived as medicines and this means that individuals do not have to add a new medication to their drugs list, an important issue for older individuals who are already taking several medications (20).

The high rate of CAM utilization by chronically ill participants $(100 \%)$ in our study to treat their chronic illness may be explained by the belief that natural is safe and the concerns and dissatisfaction for CAM use among clinicians as previously reported (11). Less than half of our participants $(41.5 \%)$ agreed about potential drug interactions with CAM modalities. In general, awareness needs to be raised in regard to the potential adverse effects (especially during pregnancy and lactation) and proven benefits of various types of CAM.

Education level, income, health status, occupation, personality variables, cultural and social beliefs are all factors that can contribute to increased use of CAM $(10,21)$. Women are more likely to use CAM than men (22), however, different patterns of use have been noted in previous research and this indicates how important it is to establish the relationship between a respondent's

Figure 2 Prevalence of complementary and alternative medicine modalities utilization according to weight category in a sample of Jordanian women women $(n=818)$ : herbal dietary supplements and nonprescription medication (Liponet ${ }^{\circledR}$ is chitosan and ascorbic acid; Garslim ${ }^{\circledR}$ is Garcinia cambogia extract), 2015

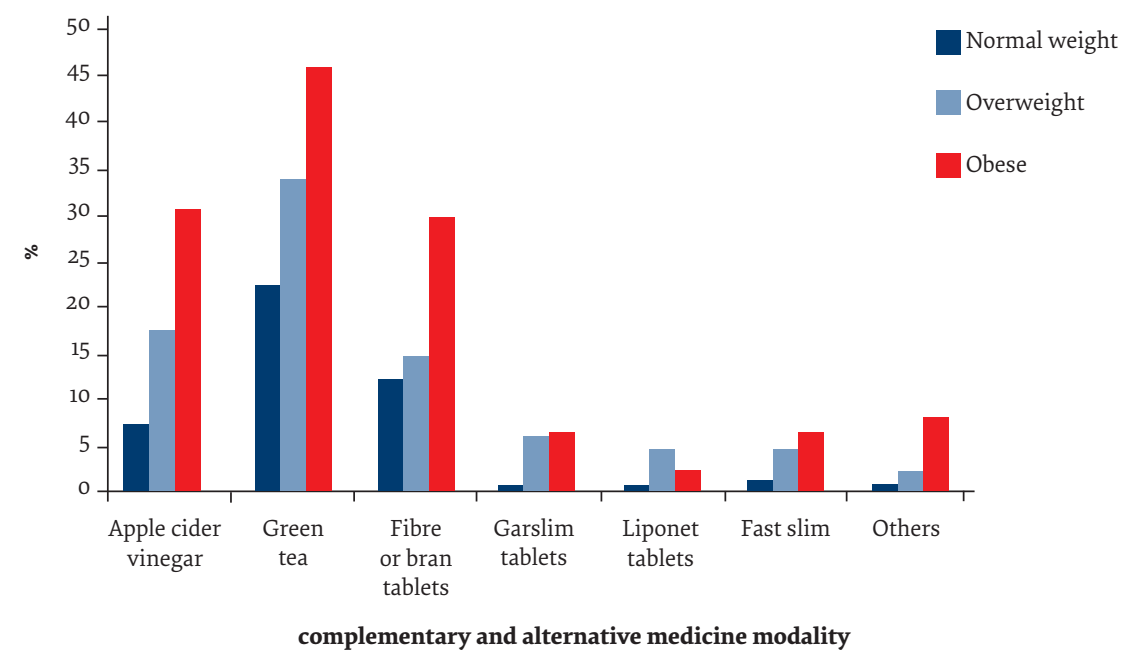


Figure 3 Prevalence of complementary and alternative medicine modality utilization by weight category in a sample of Jordanian women $(\mathbf{n}=818)$ : commercial dietary supplements, 2015

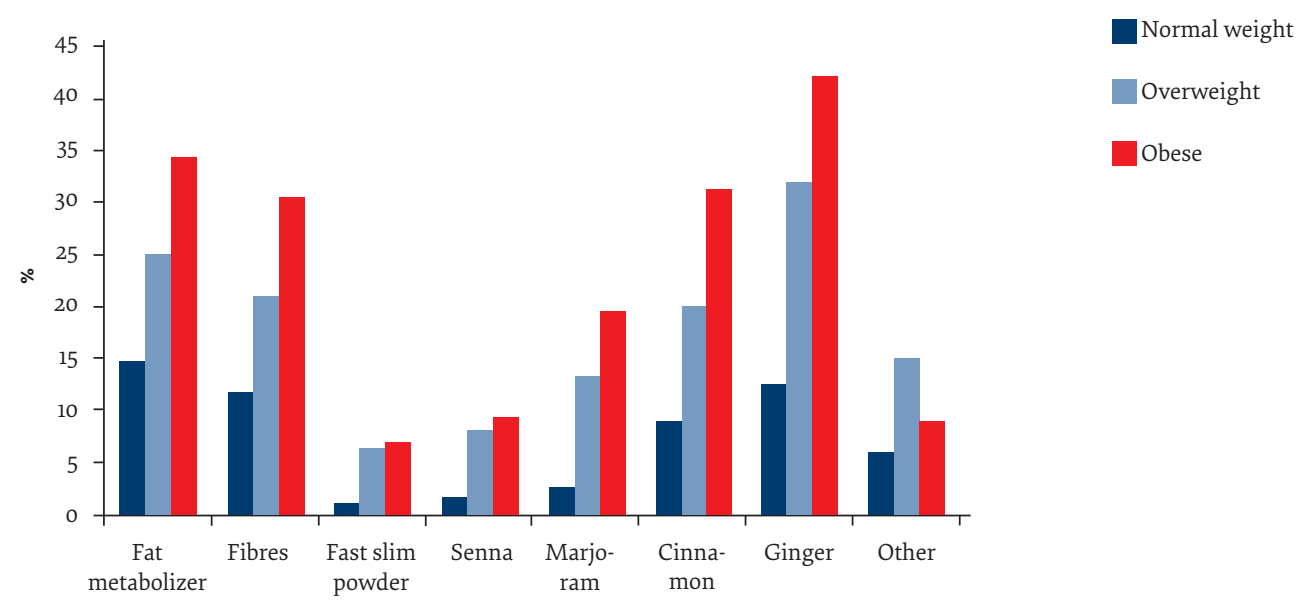

complementary and alternative medicine modality

baseline characteristics and utilization of CAM therapy (21). For example, in Hispanic women, CAM use is more common among those whose income, education level, and proficiency in English are low $(23,24)$. In our study, university students and housewives were more likely to use CAM compared with other categories.

Almost third of the participants (31.9\%) think that CAM is safe, only $41.5 \%$ think that herbs might interact with medications and almost half $(49.7 \%)$ were aware of possible side-effects induced by CAM. These beliefs need to be addressed, especially since many overweight and obese participants have chronic disorders as seen from Table 2. Knowledge regarding the potential harm of CAM use during pregnancy and lactation was reported by almost half of the women in our study. These findings are similar to the data reported by Low Dog (25). Maternity

\begin{tabular}{|c|c|c|c|c|}
\hline complementary and alternative medicine modality & $\boldsymbol{\beta}$ & P-value & OR $(95 \% \mathrm{CI})$ & $\%$ \\
\hline \multicolumn{5}{|l|}{ Herbal remedies } \\
\hline Overweight & -0.48 & 0.70 & $0.60(0.05-6.95)$ & 55.00 \\
\hline Obese & -1.24 & 0.32 & $0.30(0.03-3.26)$ & 14.50 \\
\hline Normal (R) & - & - & - & - \\
\hline \multicolumn{5}{|l|}{ Commercial dietary products } \\
\hline Overweight & -0.42 & 0.68 & $0.6(0.09-4.80)$ & 39.76 \\
\hline Obese & -0.69 & 0.50 & $0.5(0.07-3.65)$ & 20.30 \\
\hline Normal (R) & - & - & - & - \\
\hline \multicolumn{5}{|l|}{ Acupuncture } \\
\hline Overweight & -16.19 & 0.99 & $0.00(-)$ & 5.91 \\
\hline Obese & -18.48 & 0.99 & $0.00(-)$ & 0.69 \\
\hline Normal (R) & - & - & - & - \\
\hline \multicolumn{5}{|l|}{ Aromatherapy } \\
\hline Overweight & 2.50 & 0.06 & $12.20(0.96-153.58)$ & 96.00 \\
\hline Obese & 1.50 & 0.23 & $4.50(0.39-52.11)$ & 97.60 \\
\hline Normal (R) & - & - & - & - \\
\hline \multicolumn{5}{|l|}{ Herbal dietary supplements } \\
\hline Overweight & -0.18 & 0.89 & $0.80(0.07-9.43)$ & 62.57 \\
\hline Obese & -0.35 & 0.78 & $0.70(0.06-7.92)$ & 49.93 \\
\hline Normal (R) & - & - & - & - \\
\hline
\end{tabular}

$\mathrm{OR}=$ odds ratio; $\mathrm{CI}=$ confidence interval using forward Wald method; $\mathrm{R}=$ reference group.

BMI: normal $=18.5$ to $<25 \mathrm{~kg} / \mathrm{m}^{2} ;$ overweight $=25.0$ to $<30 \mathrm{~kg} / \mathrm{m}^{2} ;$ obese $=\geq 30 \mathrm{~kg} / \mathrm{m}^{2}$ 


\begin{tabular}{|c|c|c|c|c|c|c|}
\hline \multirow[t]{2}{*}{ Question } & \multicolumn{2}{|c|}{ Yes } & \multicolumn{2}{|c|}{ No } & \multicolumn{2}{|c|}{ Don't know } \\
\hline & No. & $\%$ & No. & $\%$ & No. & $\%$ \\
\hline CAM is safe & 261 & 31. 9 & 251 & 30.6 & 271 & 33.1 \\
\hline CAM might interact with medications & 340 & 41.5 & 153 & 18.7 & 289 & 35.3 \\
\hline CAM might be allergenic & 291 & 35.5 & 182 & 22.2 & 306 & 37.4 \\
\hline CAM might have side effects & 407 & 49.7 & 157 & 19.2 & 217 & 26.5 \\
\hline CAM is safe during pregnancy & 60 & $7 \cdot 3$ & 430 & 52.5 & 289 & 35.3 \\
\hline CAM is safe during lactation & 55 & 6.7 & 393 & 48.0 & 294 & 35.9 \\
\hline
\end{tabular}

CAM complementary and alternative medicine

care providers and health care professionals need to address the safety of CAM use among females through health awareness campaigns.

Biomedical maternity care providers and complementary medicine health care professionals can use this information to inform their best practice and care when working with pregnant and breastfeeding women

This study had several limitations which should be considered for interpretation purposes. First, because of the limited number of participants and the relative homogeneity of our sample, causal associations could not be established. It was very difficult to apply a random sampling method in this study as this requires a means of naming and/or numbering the target population, which was not easy to achieve. Second, we relied on self-reported data; some participants did not adequately identify their answer 'no answer' and this limited our ability a detailed review. Third, given the low number of participants with mild, moderate and extreme obesity, we were unable to detect differences in CAM use among obese categories.

\section{Conclusion}

Our findings indicated that CAM use rates are similar for weight control or reduction and these could be attained by a variety of alternative modalities. In addition, participants use CAM in combination with other practices involving the restricted calories intake and/or medications for weight reduction. Awareness about the safety of CAM modalities utilization concurrently with medications and during special physiological conditions, pregnancy and lactation should be addressed. Healthy diet and lifestyle public programs need to be initiated and encouraged by decision makers and authorities in order to limit the rising percentage of overweight and obesity among university students and unemployed.

\section{Acknowledgements}

The authors would like to acknowledge the Deanship of the Scientific Research.

Funding: The University of Jordan provided the financial support for this study (Grant number 1532).

Competing interests: None declared.

\section{Recours aux médecines complémentaires et alternatives dans le cadre de la gestion du poids chez les femmes en Jordanie : enquête communautaire}

\section{Résumé}

Contexte : Le lien entre obésité et plusieurs maladies chroniques est clairement attesté. En Jordanie, la prévalence du surpoids $(30,0 \%)$ et de l'obésité $(38,8 \%)$ chez les femmes est en augmentation, incitant ainsi de nombreux adultes à se tourner vers les méthodes de soins alternatives en vue de gérer leur poids.

Objectifs : La présente étude visait à examiner le statut du recours aux médecines complémentaires et alternatives (MCA) dans le cadre de la gestion du poids chez les femmes adultes en Jordanie et le lien possible entre cette pratique et l'indice de masse corporelle (IMC).

Méthodes : Un questionnaire structuré, administré par un enquêteur, a été utilisé en 2015 auprès de 858 femmes pour recueillir des données sur l'utilisation et la sécurité des MCA en vue de la gestion du poids. Les données ont été codées et analysées à l'aide du logiciel SPSS, version 20.

Résultats : Près de $40 \%$ des femmes interrogées indiquaient avoir recours à certaines formes de MCA en vue de gérer leur poids. Les suppléments alimentaires commercialisés (31,2\%), les remèdes à base de plantes (26,7\%) et les remèdes populaires (18,0\%) étaient couramment utilisés. Le thé vert et les comprimés de fibres étaient les compléments à base de plantes les plus largement utilisés. L'analyse de régression logistique indiquait que les participantes en surpoids recouraient plus fréquemment aux MCA que celles qui étaient obèses. En ce qui concerne les MCA, les proches et les amis 
constituaient les principales sources d'information. Seuls 31,9\% des femmes estimaient que les modalités du recours aux MCA étaient sûres ; près de la moitié pensaient que ces types de médecines n'étaient pas recommandées pendant la grossesse $(52,5 \%)$ et l'allaitement $(48,0 \%)$. Seulement $49,7 \%$ avaient connaissance des effets secondaires et $41,5 \%$ des interactions médicamenteuses.

Conclusion : Cette étude a révélé que les MCA sont souvent utilisées dans la cadre de la gestion du poids. Il convient d'augmenter la sensibilisation à l'égard de cette pratique en association avec d'autres médicaments et pendant la grossesse et l'allaitement.

$$
\begin{aligned}
& \text { استخدام الطب التكميلي و البديل للتحكم بالوزن بادئ بين الإناث في الأردن: مسح بحتمعي } \\
& \text { ميادة بشير شحادة، غدير أسعيفان، آلاء أبو عودة، رلى درويش التوزين الإن }
\end{aligned}
$$

الخلفية: هناك توثيق جيد للعلاقة بين البدانة والإصابة بمختلف الأمراض المزمنة. وفي الأردن، يزداد معدل انتشار زيادة الوزن (30.0\%) والبدانة

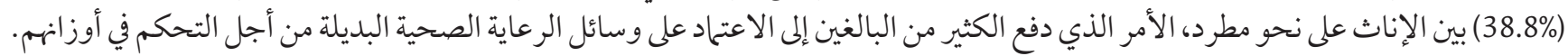

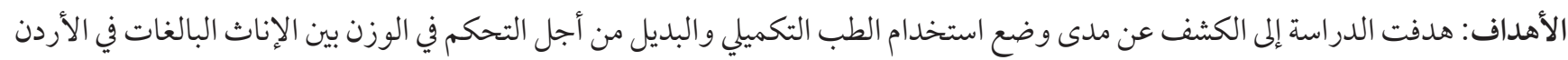

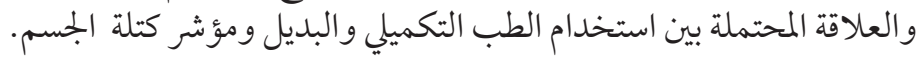

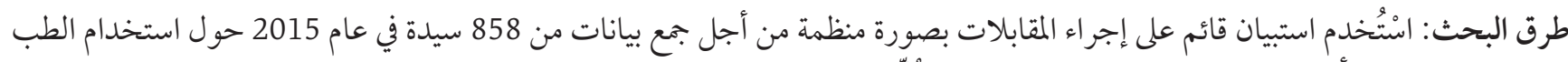

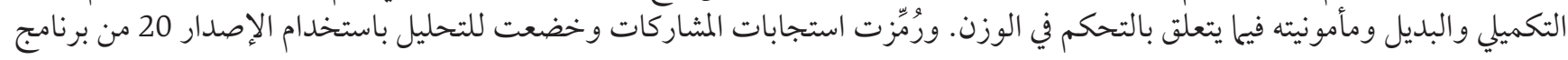

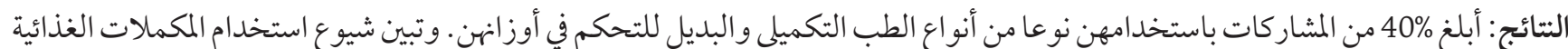

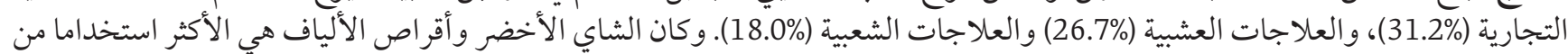

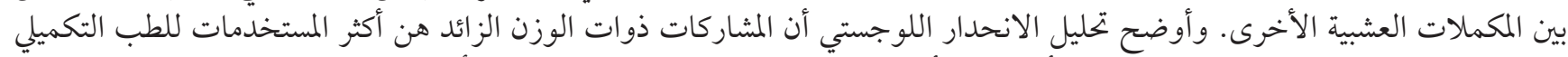

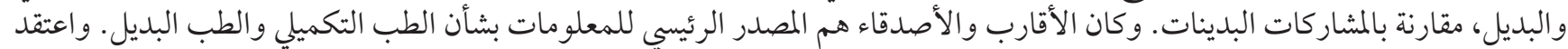

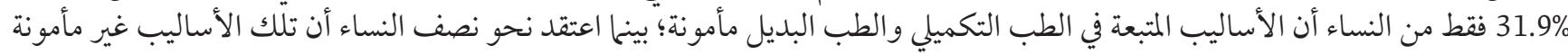

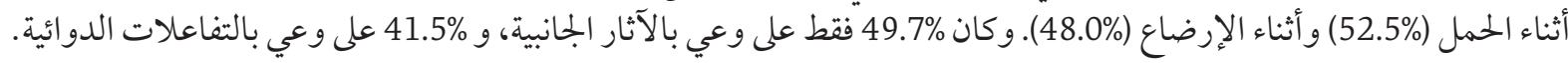

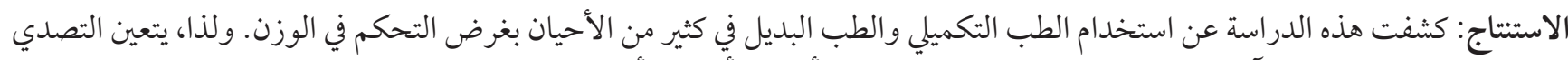

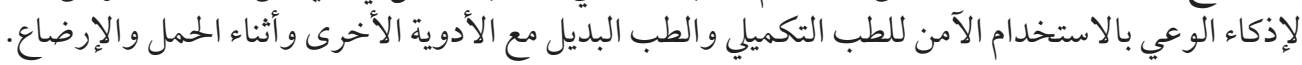

\section{References}

1. James PT. Obesity: the worldwide epidemic. Clin Dermatol. 2004;22(4):276-80. PMID:15475226

2. Al Nsour M, Al Kayyali G, Naffa S. Overweight and obesity among Jordanian women and their social determinants. East Mediterr Health J. 2014;19(12):1014. PMID:24684099

3. Khader Y, Batieha A, Ajlouni H, El-Khateeb M, Ajlouni K. Obesity in Jordan: prevalence, associated factors, comorbidities, and change in prevalence over ten years. Metab Syndr Relat Disord. 2008 Jun;6(2):113-20. doi:10.1089/met.2007.0030

4. Pittler MH, Ernst E. Dietary supplements for body-weight reduction: a systematic review. Am J Clin Nutr. 2004 Apr;79(4):529-36. PMID:15051593

5. Amariles P, González LI, Giraldo NA. Prevalence of self-treatment with complementary products and therapies for weight Loss: A randomized, cross-sectional study in overweight and obese patients in Colombia. Curr Ther Res Clin Exp. 2006 Jan;67(1):66-78. doi:10.1016/j.curtheres.2006.02.001

6. Ajlouni K, Jaddou H, Batieha A. Obesity in Jordan. Int J Obes Relat Metab Disord. 1998 Jul;22(7):624-8. PMID:9705020

7. Zoorob R, Chakrabarty S, O'Hara H, Kihlberg C. Which CAM modalities are worth considering? J Fam Pract. 2014;63(10):585. PMID:25343156

8. Sharpe PA, Blanck HM, Williams JE, Ainsworth BE, Conway JM. Use of complementary and alternative medicine for weight control in the United States. J Altern Complement Med.. 2007;13(2):217-22. doi:10.1089/act.2007.13407

9. Wazaify M, Alawwa I, Yasein N, Al-Saleh A, Afifi FU. Complementary and alternative medicine (CAM) use among Jordanian patients with chronic diseases. Complement Ther Clin Pract. 2013 Aug;19(3):153-7. doi:10.1016/j.ctcp.2013.03.001

10. Barnes PM, Bloom B, Nahin RL. Complementary and alternative medicine use among adults and children: United States, 2007. Hyattsville: US Department of Health and Human Services, Centers for Disease Control and Prevention; 2008.

11. Shehadeh M, Suaifan G, Darwish R. Complementary and alternative modalities; a new vein in weight control and reduction interventions. A pilot study in Jordan. Int J Biol Biomed. 2017;2:1-5. 
12. Calixto JB. Efficacy, safety, quality control, marketing and regulatory guidelines for herbal medicines (phytotherapeutic agents). Braz J Med Biol Res. 2000;33(2):179-89. doi:10.1590/s0100-879x2000000200004

13. Awad A, Al-Shaye D. Public awareness, patterns of use and attitudes toward natural health products in Kuwait: a cross-sectional survey. BMC Complement Altern Med. 2014 Mar 19;14:105. doi:10.1186/1472-6882-14-105

14. Abumweis S, Tayyem R, Bawadi H, Al-Hazzaa H, Abdulrahman O. Eating habits, physical activity, and sedentary behaviors of Jordanian adolescents' residents of Amman. Mediterr J Nutrit Metabol. 2014. 67-74.

15. Jordan Population and Family Health Survey. Amman: Department of Statistics; Calverton, Maryland: Macro International, 2008.

16. Thompson RL, Thomas DE. A cross-sectional survey of the opinions on weight loss treatments of adult obese patients attending a dietetic clinic. Int J Obes Relat Metab Disord. 2000 Feb;24(2):164-70. PMID:10702766

17. Foster GD, Wadden TA, Phelan S, Sarwer DB, Sanderson RS. Obese patients' perceptions of treatment outcomes and the factors that influence them. Arch Intern Med. 2001;161(17):2133-9. doi:10.1001/archinte.161.17.2133

18. Brandt PA. Coffee or tea? A prospective cohort study on the associations of coffee and tea intake with overall and cause-specfic mortality in men versus women. Eur. J. Epidemiol. 2018; 33:183-200. doi:/10.1007/s10654-018-0359-y

19. Sae-Tan S, Grove KA, Lambert JD. Weight control and prevention of metabolic syndrome by green tea. Pharmacol Res. 2011 Aug;64(2):146-54. doi:10.1016/j.phrs.2010.12.013.

20. Shehadeh M. Complementary and alternative modalities; a new vein in weight control and reduction interventions. A pilot study in Jordan. Int J Biol Biomed. 2017;2:1-5.

21. Barnes PM, Powell-Griner E, McFann K, Nahin RL, eds. Complementary and alternative medicine use among adults: United States, 2002. Seminars in Integrative Medicine; 2004:2(2):64-71.

22. Bardaweel S, Shehadeh M, Suaifan G, Kilani M-V. Complementary and alternative medicine utilization by a sample of infertile couples in Jordan for infertility treatment: Clinics-Based Survey. BMC Complement Altern Med. 2013 Feb 16;13:35. doi:10.1186/1472-6882-13-35

23. Mikhail N, Wali S, Ziment I. Use of alternative medicine among Hispanics. J Altern Complement Med. 2004;10(5):851-9. doi:10.1089/acm.2004.10.851

24. Chao MT, Wade C, Kronenberg F, Kalmuss D, Cushman LF. Women's reasons for complementary and alternative medicine use: Racial/ethnic differences. J Altern Complement Med. 2006;12(8):719-20. doi:10.1089/acm.2006.12.719

25. Low Dog T. The use of botanicals during pregnancy and lactation. Altern Ther Health Med., 2009; 15(1):54-8. PMID:19161049 